21 Martinez FD, Morgan WJ, Wright AL, Holberg CJ, Taussig LM. Diminished lung function as a predisposing factor for wheezing respiratory illness in infants. NEngl f Med 1988;319:1112-17.

22 Barnes PJ, Dollery CT, MacDermot J. Increased pulmonary alpha-adrenergic and reduced beta-adrenergic receptors in experimental asthma. Nature 1980;285: 569-71.

23 Jian-Ying $M$, She $B$. The distribution of beta-adrenergic receptors in guinea pig lungs and their changes in experimental allergic asthma. Sci China 1989;32:1208-14.
24 Bouhuys A, van de Woestijne KP. Mechanical consequences of smooth muscle relaxation. $\mathcal{f}$ Appl Physiol 1971;30:670-6.

25 Chung KF, Rogers DF, Barnes PJ, Evans TW. The role of airway microvascular permeability and plasma exudation in asthma. Eur Respir $\mathcal{F} 1990 ; 3: 329-37$.

26 Silverman M. Bronchodilators for wheezy infants? Arch Dis Child 1984;59:84-7.

27 Boschetto P, Roberts NM, Rogers DF, Barnes PJ. Effect of antiasthma drugs on microvascular leakage in guinea pig airways. Am Rev Respir Dis 1989;139:416-21.

\title{
Clinical chest radiology
}

Is the chest radiograph a special investigation or is it part of the clinical examination of the patient? It is my belief that it is the latter. As medical students we were taught that one should examine the patient first, make a provisional diagnosis, and then request the appropriate investigations, and for the most part, in the interest of financial and radiation economy, this must still be a guiding principle of diagnosis. In the practice of respiratory medicine, however, the plain chest radiograph is frequently the lynchpin of diagnosis, whether it be normal or abnormal. It was with some surprise that, as a thoracic house surgeon at Guy's Hospital, my "chief", Lord Brock, taught me to look at the chest radiograph first, then take the history and examine the patient, and finally go back to look at the radiograph. This fusion of the clinical approach and a basic investigation is an essential part of respiratory medicine. The place for the chest radiograph is in the ward at the bedside and not, as is the practice in many countries, including the USA, in the $x$ ray department on the other side of the hospital.

There are pitfalls to this approach for we may be too greatly influenced by our preconceived ideas. As a house physician at the Brompton Hospital in the 1950 s it was one of our duties to sit in a small cubicle in the outpatients department to take and record the clinical histories of the new patients attending the clinic. On one such day I had taken the histories of a Mr Brown, who was suffering from chronic bronchitis, and from a Mr Smith, who had for many years had pulmonary tuberculosis treated by a right sided artificial pneumothorax which had become infected. Mr Brown's chest radiograph was normal but that of $\mathrm{Mr}$ Smith showed a shrunken right lung with thickened and heavily calcified overlying pleura. When I had completed all the history taking I joined the consultant to whom I was attached for teaching. This eminent physician was examining Mr Brown's chest but, unfortunately, the nurse had inadvertently put $\mathrm{Mr}$ Smith's radiograph on the viewing box. I entered the room just as the consultant was saying "Yes, there is definite dullness at the right base with diminished air entry, and I detect reduction in movement of the whole of the right side."

Interpretation of the radiograph can also be overinfluenced by the clinical findings. Dullness and loss of air entry is not always the result of fluid, and I recall several patients who, after several attempted aspirations, have been found to have large diaphragmatic hernias and not fluid. Immediate provision of the film on the ward or in the outpatient clinic can cause some logistic problems for radiologists in providing a reporting service. Perhaps we should have peripatetic radiologists reporting the films on the wards, a practice which would enable better contact with clinical colleagues. As an example of this, for the past two years a radiologist has visited the intensive care unit at the Royal Brompton Hospital daily to review with the clinicians all the radiographs which are taken immediately to the unit before reporting.

IAN H KERR 